\title{
Irrigation Regimes for Apricot Trees under Different Rates of Soil Moisture Depletion
}

\author{
Soaad A. Mohamed" and T.A. Eid** \\ *Horticulture Research Institute, and ${ }^{* *}$ Soil Water and \\ Environmental Research Institute, Agriculture Research \\ Centre, Cairo, Egypt.
}
7 HIS EXPERIMENT was conducted at El-Kanater Horticultural Research Station, Kalubeia governorate through two successive seasons of 2010 and 2011 to study the effect of irrigation at 20, 40, 60 and $80 \%$ depletion from the available soil moisture on some water relations, some vegetative growth characteristics, yield, fruit quality and $\mathrm{N}, \mathrm{P}, \mathrm{K}, \mathrm{Fe}, \mathrm{Zn}$ and $\mathrm{Mn}$ leaf contents of twelve years old " Canino" cultivar apricot. Trees grown on clay loamy soil and planted at $5 \times 5$ meters apart. The results revealed that; consumptive use increased by decreasing the available soil moisture depletion (at high soil moisture). The monthly water consumptive was low after dormancy, then increased to reach the maximum during July and August and declined to minimum during October. The value of calculated crop coefficient $(\mathrm{Kc})$ was 0.71 .

Moreover, The value of water use efficiency (WUE) was higher with irrigation at $40 \%$ depletion of available soil moisture (1.21 and 1.33) compared with (0.98 and 0.97 ) obtained from irrigation at $80 \%$ depletion from available soil moisture during the two growing seasons, respectively. Vegetative growth (shoot length, shoot diameter and leaf area), fruiting parameters (fruit set percentage and yield) and fruit properties (fruit firmness, TSS and TSS/acid ratio) scored the highest significant values with irrigation at $20 \%$ and $40 \%$ depletion from the available soil moisture. While the leaf content of N, P, K, Fe and $\mathrm{Zn}$ significantly decreased when irrigation rate reduced.

Water is becoming scarce in the Mediterranean area where agriculture accounts for the vast majority of consumptive water use. It is therefore necessary to develop and implement regulated deficit irrigation (RDI) techniques in order to optimize water use without affecting crop yield. Although, water stress has a negative effect on most agricultural crops, fruit trees seem to adapt well to deficit irrigation (Costa et al., 2007). For example, apricot (Prunus armeniaca L.) trees permit the implementation of RDI during stage II of fruit development, which is known to be quite insensitive to water stress (Girona et al., 1997).

On the other hand, the world faces very serious global warming, which will will cause general warming and significant increase in evaporation and crop water requirements. Thus, irrigation efficiency is becoming more important in arid and semi-arid regions due to the limitation of water resources. 
Most apricot trees are cultivated in Mediterranean countries, where drought periods are expanded, a fact that makes irrigation water being the most limiting factor for apricot commercial production. So, optimization the efficiency of irrigation in this region by applying the deficit irrigation strategies that permit maximum yield while reducing water application is of great importance. In this sense, regulated deficit irrigation (RDI) may offer an approach to save water in some woody crops by minimizing or eliminating negative impacts on yield and crop revenue (Domingo et al., 1996 and Goldhamer, 1997).

In this respect, Ali (2006) on peach as well as Kandil and El-Feky (2006) on apricot obtained the best growth parameters and yield with $80 \%$ F.C (field capacity). Moreover, Cathoun (1975) found that increase tension from zero to 0.33 bar released more than $75 \%$ of water in light textured soil but less than $50 \%$ in heavy ones. Also, Levin et al. (1980) revealed that, root distribution depended upon the volume of wet soil, which related to soil hydraulic conductivity. The crop coefficient $(\mathrm{Kc})$ value has been used for quantifying crop water use (Doorenbos and Pruitt, 1984).

According to Girona et al. (1997), timing of water deficits has important effects on productivity of fruit trees. Kandil and El-Feky (2006) reported that water soil potential at $100-200 \mathrm{~m}$ bar $\left(12.94 \mathrm{~m}^{3} /\right.$ tree/year) was the best level for "Canino" apricot trees. On the other hand, excessive water may have adverse effects on fruit quality, since it increases vegetative growth, promoting nutritional imbalance and decreasing fruit dry mass. Consequently, it is important to study the effect of regulated deficit irrigation RDI on apricot fruit quality at harvest time.

The purpose of this study is to determine the effect of different irrigation regimes on water consumption, water use efficiency, vegetative growth, fruit set, yield, fruit quality (physical \& chemical) and leaf mineral contents of "Canino" apricot trees grown under Qalubeia government.

\section{Materials and Methods}

The present investigation was undertaken during the two successive seasons of 2010 and 2011 at the Experimental Farm, El-Kanater Horticultural Research Station, Kalubeia Governorate ( Latitude: $30^{\circ} .08 \mathrm{~N}$ Longitude: $31^{\circ} .15$ Elevation: $16.9 \mathrm{~m}$ ) fruitful trees of "Canino" apricot (Prunus armeniaca L.) budded on apricot seedlings rootstock. The selected trees were about twelve years old grown on clay loamy soil and planted at $5 \times 5$ meters apart. Trees were carefully selected as being healthy and approximately uniform in their vigour, shape and size and received regularly the common horticultural practices in the region.

Analyses of the soil physical properties and the constant of soil moisture content are shown in Table 1. Meteorological data for the Agricultural Research Station is shown in Table 2.

Egypt. J. Hort. Vol. 40, No.2 (2013) 
TABLE 1. Physical properties of soil of the experiment .

\begin{tabular}{|c|c|c|}
\hline Parameter & & Value \\
\hline \multicolumn{3}{|c|}{ Particle size distribution (\%): } \\
\hline Clay & $\%$ & 30.4 \\
\hline Silt & $\%$ & 34.5 \\
\hline Fine sand & $\%$ & 34.1 \\
\hline Coarse sand & $\%$ & 1.0 \\
\hline Texture class & & Clay loam \\
\hline
\end{tabular}

Water parameters and bulk density

\begin{tabular}{|c|c|c|c|c|c|c|c|}
\hline \multirow{2}{*}{ Depth } & \multicolumn{2}{|c|}{$\begin{array}{c}\text { Field capacity } \\
\text { (FC) }\end{array}$} & \multicolumn{2}{c|}{$\begin{array}{c}\text { Wilting Point } \\
\text { (WP) }\end{array}$} & \multicolumn{2}{c|}{$\begin{array}{c}\text { Available water } \\
\text { (AW) }\end{array}$} & \multicolumn{2}{c|}{$\begin{array}{c}\text { Bulk } \\
\text { density } \\
\text { (BD) } \\
\text { Mg/m }\end{array}$} \\
\cline { 2 - 7 } & $\begin{array}{c}\text { \% by } \\
\text { weight }\end{array}$ & Cm & $\begin{array}{c}\text { \% by } \\
\text { weight }\end{array}$ & cm & $\begin{array}{c}\text { \% by } \\
\text { weight }\end{array}$ & cm & \\
\hline $0-15$ & 37.9 & 6.99 & 18.6 & 3.43 & 19.3 & 3.56 & 1.23 \\
\hline $15-30$ & 35.8 & 6.39 & 17.8 & 3.18 & 18.0 & 3.21 & 1.19 \\
\hline $30-45$ & 32.1 & 6.12 & 16.1 & 3.07 & 16.0 & 3.05 & 1.27 \\
\hline $45-60$ & 31.7 & 7.32 & 15.9 & 3.67 & 15.8 & 3.65 & 1.54 \\
\hline Total & & 26.82 & & 13.35 & & 13.47 & \\
\hline
\end{tabular}

The experimental design was a randomized complete blocks with three replicates was used. The investigation was designed to test four irrigation treatments.

Irrigation treatments were as follows:

- Irrigation when $20 \%$ of available soil moisture is depleted $\left(\mathrm{I}_{1}\right)$.

- Irrigation when $40 \%$ of available soil moisture is depleted $\left(\mathrm{I}_{2}\right)$.

- Irrigation when $60 \%$ of available soil moisture is depleted $\left(\mathrm{I}_{3}\right)$.

- Irrigation when $80 \%$ of available soil moisture is depleted $\left(\mathrm{I}_{4}\right)$

Irrigation started after trees received the winter irrigation on March i.e., starting from bud swelling stage. Irrigation was done when moisture reached the relevant level (5 days after irrigation) to determine available soil water retained in the soil in each treatment.

Soil moisture was determined grave metrically on oven dry basis of soil samples taken to a depth of $15 \mathrm{~cm}$ up to $60 \mathrm{~cm}$. Water consumption was computed as the differences of soil moisture content in soil samples taken prior to 48 hour after irrigation. 
TABLE 2. Meteorological data in 2010 and 2011 seasons .

\begin{tabular}{|l|c|c|c|c|c|c|c|c|c|c|c|c|c|c|}
\hline Season & \multicolumn{10}{|c|}{2010} \\
\hline Month & T.max & T.min. & W.S & R.H. & S.S & S.R & R.F & T.max & T.min. & W.S & R.H. & S.S & S.R & R.F \\
\hline Feb. & 25.0 & 11.5 & 1.5 & 57.7 & 11.0 & 354 & 6.1 & 22.9 & 11.3 & 1.3 & 56.7 & 11.0 & 354 & 0.7 \\
Mar. & 27.1 & 13.9 & 1.9 & 60.0 & 11.8 & 441 & 0.0 & 24.8 & 11.9 & 1.8 & 57.3 & 11.8 & 441 & 0.4 \\
Apr. & 29.6 & 16.0 & 1.8 & 52.3 & 12.8 & 419 & 0.0 & 28.4 & 18.5 & 1.4 & 51.0 & 12.8 & 519 & 0.4 \\
May & 33.9 & 19.2 & 1.7 & 49.0 & 13.5 & 585 & 0.0 & 32.8 & 18.7 & 1.7 & 50.3 & 13.5 & 585 & 0.1 \\
Jun. & 37.0 & 22.7 & 1.6 & 51.3 & 13.9 & 627 & 0.0 & 35.2 & 21.7 & 2.0 & 54.7 & 13.9 & 627 & 0.0 \\
Jul. & 36.3 & 23.9 & 1.8 & 67.0 & 13.8 & 613 & 0.0 & 37.3 & 23.5 & 1.9 & 58.7 & 13.8 & 613 & 0.0 \\
Aug. & 38.3 & 25.3 & 1.8 & 60.7 & 13.1 & 577 & 0.0 & 3.5 & 23.9 & 1.6 & 61.5 & 13.2 & 577 & 0.0 \\
Sep. & 35.8 & 23.5 & 2.1 & 59.0 & 12.2 & 512 & 0.0 & 35.5 & 22.7 & 0.9 & 58.0 & 12.2 & 512 & 0.0 \\
Oct. & 33.8 & 21.5 & 1.9 & 59.0 & 11.3 & 417 & 0.0 & 33.0 & 20.3 & 1.0 & 59.3 & 11.3 & 417 & 0.0 \\
\hline
\end{tabular}

Where: T.max., T.min.: maximum and minimum temperatures ${ }^{\circ} \mathrm{C}$; W.S : wind speed $(\mathrm{m} / \mathrm{sec})$; R.H.: relative humidity (\%); S.S: actual sun shine (hour); S.R: solar radiation (cal/ $\left.\mathrm{cm}^{2} / \mathrm{day}\right)$. RF: rainfall (mm / month).

[Data were obtained from the agrometeorological Unit at SWERI, ARC]

The quantity of irrigation water applied to each "Canino" apricot tree (litters) and per feddan $\left(\mathrm{m}^{3}\right)$ in the different irrigation treatments during each growing season was calculated.

\section{Calculation of water consumptive use (CU)}

Water consumptive use or actual evapotranspiration (ETc) values were calculated for each irrigation using the following formula (Israelsen and Hansen, 1962).

$$
W C U=\sum_{i=1}^{i=4} \frac{\left(\theta_{2}-\theta_{1}\right)}{100} \times B d \times D
$$

Where:

WCU = seasonal water consumptive use $(\mathrm{cm})$,

$\Theta_{2} \quad=$ soil moisture content after irrigation (on mass basis, \%),

$\Theta_{1} \quad=$ soil moisture content before irrigation (on mass basis, \%),

$\mathrm{Bd} \quad=$ soil bulk density $\left(\mathrm{g} / \mathrm{cm}^{3}\right)$,

$\mathrm{D} \quad=$ depth of soil layer $(15 \mathrm{~cm}$ each $)$, and

$\mathrm{i} \quad=$ number of soil layer.

\section{Calculation of crop coefficient and evapotranspiration}

Reference evapotranspiration (ETo)

Reference evapotranspiration (ETo) was calculated using the meteorological data using three formulae as cited by Doorenbos and Pruitt, (1977) and Allen et al., (1998) as follows:

Doorenbos - Pruitt equation

The equation adapted the radiation formula of Makkink (1957) to predict potential evapotranspiration as follows:

ETp: bw Rs/L- 0.3

Where: ETp: Daily potential evapotranspiration ( $\mathrm{mm} /$ day).

$\mathrm{b}$ : Adjustment factor based on wind and mean relative humidity.

$\mathrm{W}$ : Weighting factor based on temperature and elevation above sea level.

Egypt. J. Hort. Vol. 40, No.2 (2013) 
Rs: Daily total incoming solar radiation for the period of consideration (cal/ $/ \mathrm{cm}^{2} /$ day).

L: Latent heat of vaporization of water $\left(\mathrm{cal} / \mathrm{cm}^{2} /\right.$ day)

Factors (b) and (w) could be obtained from the tables cited by (Doorenbos and Pruitt 1977).

Penman- Monteith equation

For estimating potential evapotranspiration of Penman Monteith, it was applied by using CROP WAT model (Smith 1991) as follows :

$\mathrm{ETo}=$ $0.408 \Delta(\mathrm{Rn}-\mathrm{G})+\gamma\left[900 /(\mathrm{T}+273] \mathrm{U}_{2}\left(\mathrm{e}_{\mathrm{s}}-\mathrm{e}_{\mathrm{a}}\right)\right.$

$$
\Delta+\gamma\left(1+0.34 \mathrm{U}_{2}\right)
$$

ETo: reference evapotranspiration, $\mathrm{mm} /$ day

$\mathrm{Rn}$ : net radiation (MJm-2d-1)

G: soil heat flux (MJm-2d-1)

$\Delta$ : slope vapor pressure and temperature curve $\left(\mathrm{kPa}^{\circ} \mathrm{C}-1\right)$

$\gamma$ : psychrometric constant $\left(\mathrm{kPa}{ }^{\circ} \mathrm{C}-1\right)$.

$\mathrm{U} 2:=$ wind speed at $2 \mathrm{~m}$ height (ms-1).

es-ea: vapor pressure deficit $(\mathrm{kPa})$.

$\mathrm{T}$ : mean daily air temperature at $2 \mathrm{~m}$ height $\left({ }^{\circ} \mathrm{C}\right)$.

Pan evaporation equation

ETo: $\mathrm{K}_{\mathrm{pan}} \times \mathrm{E}_{\mathrm{pan}}$

Where:

ETo: reference evapotranspiraton ( $\mathrm{mm} /$ day).

$\mathrm{K}_{\mathrm{pan}}$ : Pan Coefficient

$\mathrm{E}_{\mathrm{pan}}$ : Pan evaporation in $\mathrm{mm} / \mathrm{day}$ from an unscreened class A type.

Crop coefficient $(\mathrm{Kc})$ and assessment of ET

Three different equations were used to assess the extent of closeness of each estimate with the actual values obtained by direct measurement (values shown by the $\mathrm{I}_{2}$ treatment which is the medium treatment). These equations are (1) the Penman - Monteith equation using the CROPWAT model and (2) the Doorenobs and Pruitt (1977) and equation (3) the Pan Evaporation equation

\section{Crop Coefficient (Kc)}

The recommended values of Kc, according to Doorenbos and Kasam (1986) were used to estimate the ETo for the conditions of the area where the experiment was done. The formula is as follows:

$$
\mathrm{Kc}=\mathrm{Etc} / \mathrm{ETo}
$$

Where: Kc : Crop coefficient.

ETc : The measured (actual) evapotranspition of a considered period ( $\mathrm{mm} /$ day)

Eto : reference evapotranspiration ( $\mathrm{mm} / \mathrm{day})$ referring to the same period, calculated as average value of three formulae.

Egypt. J. Hort. Vol. 40, No.2 (2013) 
Water use efficiency (WUE)

Water use efficiency (WUE) is used to describe the relationship between production and the amount of water used. It was determined according to the following equation (Vites 1965):

Fruits yield $(\mathrm{kg}) / \mathrm{fed}$

W.U.E $=$

$$
\text { Seasonal ET }\left(\mathrm{m}^{3 /} \text { water consumed }\right) / \text { fed }
$$

Vegetative growth measurements

Four main branches, in different directions of each replicate were labeled. All current shoots developed on those branches on Aug. were used for measuring vegetative growth parameters as follows: a) Shoot length (cm), b) Shoot diameter $(\mathrm{cm})$, c) Leaf area $\left(\mathrm{cm}^{2}\right)$ using Li-core 3100 area meter. Leaves were dried and weighed to get d) Leaf dry weight (g.).

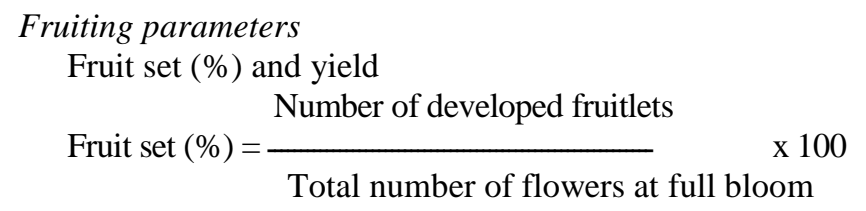

Yield

At harvest time, yield of each tree was recorded as $\mathrm{kg}$ per tree during the two seasons of study.

Samples of twenty fruits from each replicate under treatment at harvest were randomly collected and the following characters were determined as follows:

\section{Fruit quality}

Physical fruit properties

Fruit weight $(\mathrm{g})$, fruit size $\left(\mathrm{cm}^{3}\right)$, length $(\mathrm{cm})$, diameter $(\mathrm{cm})$ and firmness. Firmness was determined by Magness and Taylor (1925), pressure tester using $7 / 18$ inch plunger two reading were taken on the fresh of each fruit.

\section{Chemical fruit properties}

- Total soluble solids (\%) in fruit juice was determined by using hand refractometer.

- b-Titratation table acidity (\%) was measured according to (A.O.A.C. 1990) and Vogel (1968).

- Total soluble solids/acidity ratio was calculated.

- Total sugars were calculated color-metrically according to Malik and Singh (1980).

\section{Leaf analysis}

Leaf nutrient composition

Twenty mature mid-shoot leaves at mid August of both seasons were collected randomly, and then washed with tap water followed by distilled water and oven dried at $70{ }^{\circ} \mathrm{C}$ to constant weight and prepared for the determination of leaf mineral content.

Egypt. J. Hort. Vol. 40, No.2 (2013) 
Nitrogen was estimated using micro-Kjeldahl method described by Pregl (1945). Phosphorus was determined with a colorimetric method as described by Snell and Snell (1967). Potassium was determined by using the Atomic Absorption Spectrophotometer. Iron, zinc and manganese were determined by Atomic Absorption Spectrophotometer according to Jackson and Ulrich (1959) and Chapman and Pratt (1961). Generally, all macro-elements were expressed as percent, while micro-elements were expressed as (ppm) on dry weight basis.

\section{Leaf total chlorophyll content}

Leaf total chlorophyll values were determined by using portable Minolta chlorophyll Meter (Model SPAD-501). Leaf samples collected in mid-June and the reading was taken at the middle of leaf blade according to Murquard and Timpton (1987).

The experimental design was a randomized complete block design and all data obtained throughout the course of this study were statistically analyzed by the analysis of variance as described by Snedecor and Cochran (1990). Differences between treatments were compared by Duncan's (1955) multiple range tests.

Water use

\section{Results and Discussion}

The consumptive use of water (CU) measured actually during the season (considered as actual evapotranspiration, i.e. actual ET) as affected by the different treatments and the calculated crop coefficient with comparison of actual and calculated ET are presented and discussed bellow, as well as water use efficiency WUE.

\section{Water consumptive use}

Seasonal Rates $\left(\mathrm{m}^{3}\right)$

Seasonal rates of water consumptive use (CU) by trees under different soil moisture stress treatments are presented in Fig. 1. The values of water use show that the short irrigation intervals (i.e. the wet $\mathrm{I}_{1}$ regime) followed by the $\mathrm{I}_{2}$ then dry regime $\mathrm{I}_{3}$ gave the lowest. ETa values in 2010 were 4746, 4363.8,3691.8 and $3359.2 \mathrm{~m}^{3}$ for $\mathrm{I}_{1}, \mathrm{I}_{2}, \mathrm{I}_{3}$ and $\mathrm{I}_{4}$, respectively. The same respective values in 2011 were $4846.8,4460.4,4032$ and $3493.1 \mathrm{~m}^{3}$. The values showed that seasonal water uses by trees are higher in the second than in the first season. Such results are mainly due to the differences in weather factors such as the increasing in air temperatures.

Increased $\mathrm{CU}$ with increasing soil moisture content is a direct consequence of increased irrigation water input in addition to the higher evaporation rate from wet soil surface. Abd Alla et al. (1990) found that, the highest CU occurred when irrigation was done upon reaching moisture of 70 to $80 \%$ of the field capacity. Ibrahim (1981) concluded that the increase in evapotranspiration by maintaining soil moisture at a high level is attributed to excess available water in the root zone. Unger and Steward (1983) pointed out that, soil water evaporation 
occurs in three stages. In the first, water loss is rapid and steady, and depends on the net effects of water transmission to the surface and on environmental conditions. In the second stage, the loss rate decreases rapidly as the soil water supply is depleted, and soil factors control the rate of water movement to the surface and above ground. In the third stage, evaporation is extremely slow and is controlled by absorptive factors at the liquid-solid interface. Doorenbos and Pruitt (1984) concluded that, after irrigation the soil water content decreases primarily by evapotranspiration.

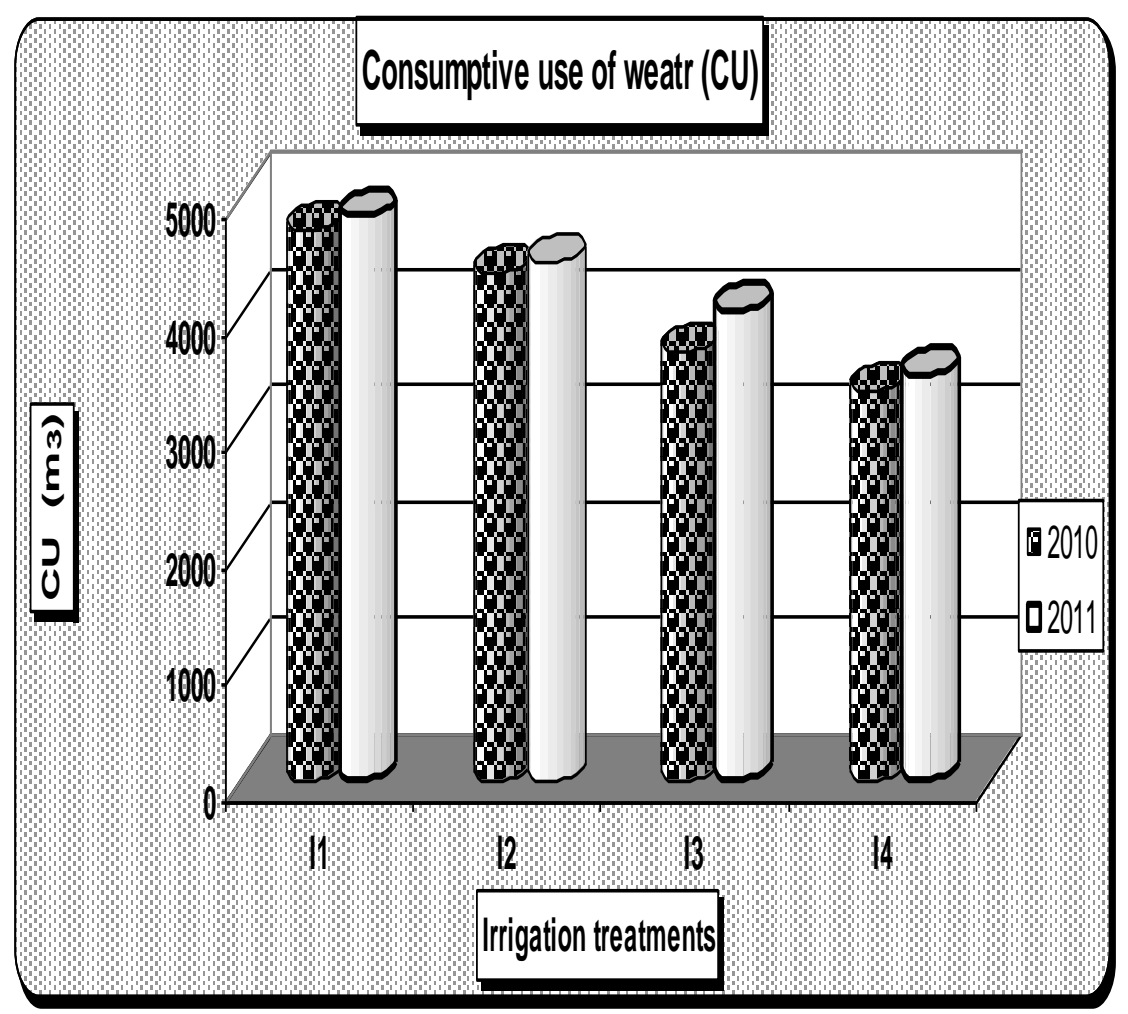

Fig. 1.Effect of irrigation treatments on water consumptive use (CU) $\mathrm{mm}$ of apricot trees.

As the soil dries, the rate of water transmitted through the soil is reduced. When the rate of flow falls below the rate needed to meet ET of crop, it will fall below its predicted level. Chang (1971) concluded that the rate of evapotranspiration depends on the evaporate power of air and there was a very close correlation of water consumptive use and climate. The pattern of consumptive use was $I_{1}>I_{2}>I_{3}>I_{4}$ is a manifestation of greater water availability of soil moisture to plants. High evaporation would occur from a relatively wet rather than a relatively dry soil surface. Higher CU with the wet regime can be attributed to greater availability of soil water to apricot trees in addition to the higher evaporation rate from wet soil surface.

Egypt. J. Hort. Vol. 40, No.2 (2013) 
Monthly consumptive use

Monthly CU Fig. 2 was low at the beginning of the growth season (after dormancy). This can be related to less transpiring surface (leaves) during the period of bloom. Potential evapotranspiration was low through this period Table 3, then increased gradually as the green cover increased with increases in air temperature and solar radiation. The highest $\mathrm{CU}$ occurred during July reflecting: a) expansion of the leaf system, b) growth of fruit on a volume basis, c) high solar radiation and air temperature. The July values for the treatments averaged 741.3, $694.3,628.3$ and $582.1 \mathrm{~m}^{3}$ for $\mathrm{I}_{1}, \mathrm{I}_{2}, \mathrm{I}_{3}$ and $\mathrm{I}_{4}$ (means of the 2 seasons), respectively.

Thereafter, evapotranspiration rate decline to reach its minimum value during October as the trees were approaching dormant period . Such results can be attributed to high evaporation than transpiration early in the season (blooming period) as plants intercepts little of net radiation. Later, as the green cover expanded, transpiration was greater than evaporation. Thus, the increase in evapotranspiration from the beginning of the growth season till fruit maturity can be explained on the basis of the cover. It can be concluded that soil moisture stress has a direct effect on monthly evapotranspiration of trees as soil moisture stress increased by prolonged irrigation intervals. Smajstrla and Koo (1984) found that irrigation of selected trees was initiated during the growth stages before and after June. They suggested that irrigation is required to keep soil moisture tension between $40-60$ mbar at $30 \mathrm{~cm}$ soil depth (i.e. $50 \%$ available water) and this frequency of water application resulted in the highest yields.

TABLE 3. Monthly water consumptive use Eta $\left(\mathrm{m}^{3}\right)$ by apricot trees under different water regime levels.

\begin{tabular}{|c|c|c|c|c|c|c|c|c|c|c|}
\hline \multirow{2}{*}{$\begin{array}{c}\text { Irrigation } \\
\text { regimes }\end{array}$} & \multicolumn{10}{|c|}{$\mathbf{2 0 1 0}$} \\
\cline { 2 - 10 } & Febr. & Mar. & Apr. & May & June & July & Aug. & Sep. & Oct. & Total \\
\hline $\mathbf{I}_{\mathbf{1}}$ & 242.34 & 451.08 & 510.3 & 612.78 & 659.4 & 699.3 & 584.64 & 507.78 & 478.38 & 4746.0 \\
$\mathbf{I}_{\mathbf{2}}$ & 236.46 & 386.82 & 457.8 & 559.44 & 600.6 & 682.08 & 572.46 & 466.2 & 401.94 & 4363.8 \\
$\mathbf{I}_{\mathbf{3}}$ & 232.26 & 325.92 & 380.52 & 486.78 & 546.42 & 571.2 & 517.44 & 399 & 232.26 & 3691.8 \\
$\mathbf{I}_{\mathbf{4}}$ & 226.8 & 271.32 & 338.52 & 461.58 & 505.68 & 533.4 & 471.24 & 356.16 & 194.46 & 3359.2 \\
\hline & \multicolumn{10}{|c|}{$\mathbf{2 0 1 1}$} \\
\hline & Febr. & Mar. & Apr. & May & June & July & Aug. & Sep. & Oct. & Total \\
\hline $\mathbf{I}_{\mathbf{1}}$ & 254.1 & 460.32 & 517.02 & 593.46 & 693.42 & 741.3 & 639.24 & 504.84 & 443.1 & 4846.8 \\
$\mathbf{I}_{\mathbf{2}}$ & 236.46 & 395.22 & 466.2 & 571.2 & 613.2 & 694.26 & 606.06 & 464.1 & 413.7 & 4460.4 \\
$\mathbf{I}_{\mathbf{3}}$ & 231.42 & 371.28 & 403.62 & 540.12 & 604.38 & 628.32 & 556.92 & 422.52 & 273.42 & 4032.0 \\
$\mathbf{I}_{\mathbf{4}}$ & 227.22 & 329.28 & 365.82 & 409.92 & 545.16 & 582.12 & 501.48 & 330.12 & 202.02 & 3493.1 \\
\hline
\end{tabular}

\section{Crop coefficient "Kc"}

Factors affecting values of crop coefficient $(\mathrm{Kc})$ are mainly the climatic conditions, crop characteristics, sowing date, rate of crop development and length of growing season. Results of the current study (Table 4) show that the mean value of $\mathrm{Kc}$ was 0.71 . Monthly values increased with time and was higher in June, July and August $(0.65,0.74$ and 0.63$)$, respectively. This demonstrates that such period is the peak of water demand. The crop coefficient decreased again during the late season to reach minimum when plants were reaching dormancy .

Egypt. J. Hort. Vol. 40, No.2 (2013) 
Most crops do not require much water during the season as would be needed to meet the potential evapotranspiration, even though adequate soil moisture can be provided (Jensen, 1968). Thus, the term crop coefficient is used to differentiate water requirements of crops. For the determination of crop coefficient, both actual and potential evapotranspiration are measured concurrently.
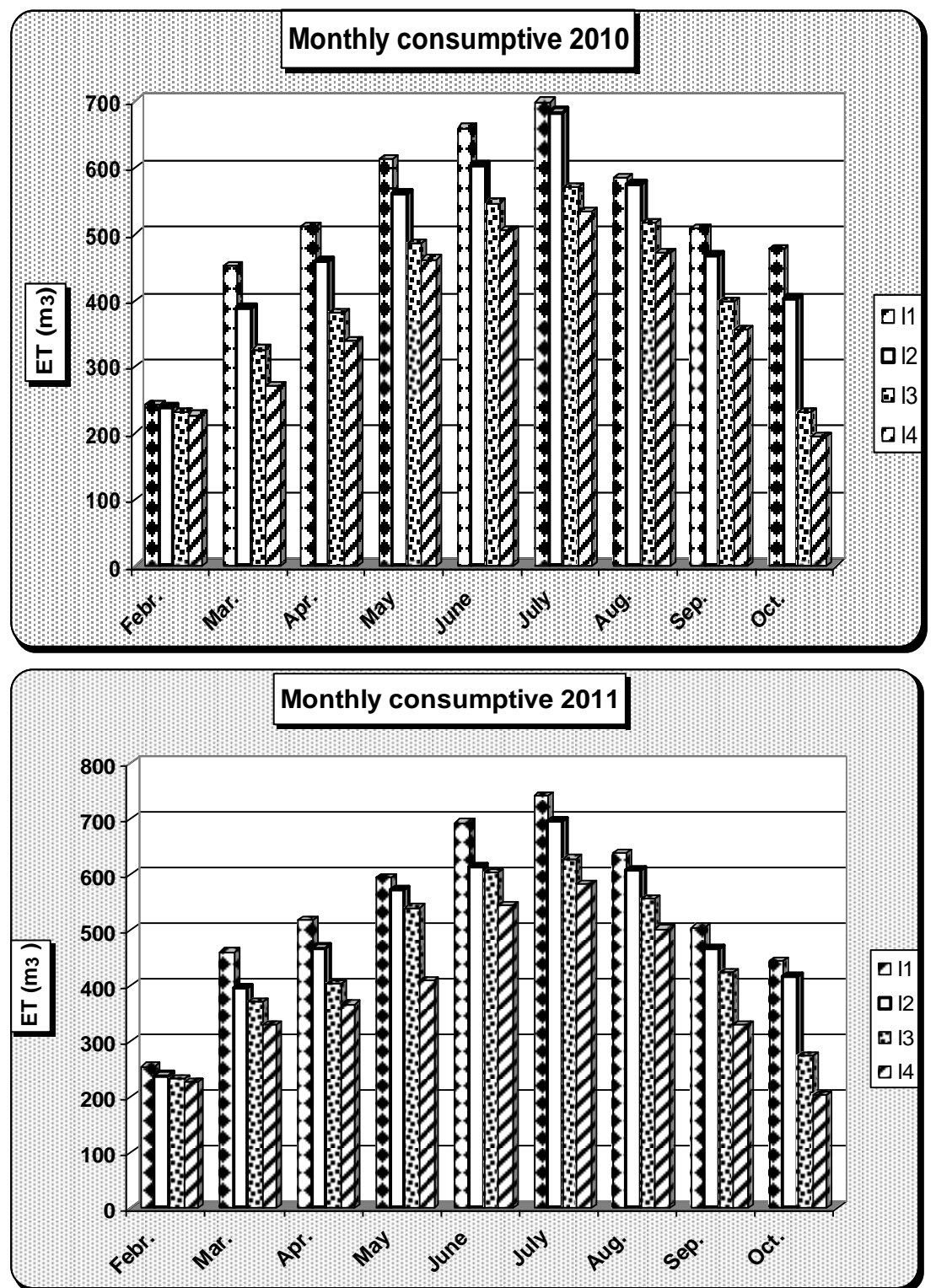

Fig. 2. Monthly water consumptive use Eta $\left(\mathrm{m}^{3}\right)$ by apricot trees under different water regime levels.

Egypt. J. Hort. Vol. 40, No.2 (2013) 
Comparing actual ETa with calculated ETp

Evapotranspiration (ETp) crop values Table 4 calculated using the three different equations (Penman - Monteith, Doorenbos - Pruitt and Evaporation Pan) were compared with the actual ETa as obtained by actual measurement i.e. the consumptive use. In season 2010, seasonal ETp values were 1605, 1353 and $1034 \mathrm{~mm}$ for the Penman - Monteith, Doorenbos - Pruitt and Evaporation Pan equations, respectively. In season 2011, seasonal ETp values were 1528, 1327 and $1138 \mathrm{~mm}$ for the same respective equations.

Generally, results indicate that there were differences among calculations using the different equations. The Doorenbos - Pruitt equation was the second highest estimate preceded by the Penman - Monteith equation. The evaporation pan showed great differences between the two seasons, which reflects differences in weather conditions particularly temperature and solar radiation temperature. The Penman - Monteith formula gave the highest ETp crop value, while the Evaporation Pan equation gave the lowest one in the two seasons. Comparison with ETa as calculated by actual determination shows that the Evaporation A Pan equation was the nearest to actual ET.

Comparison between the calculated ETp and the actual ETa

Value of ratios of ET (i.e. crop ET/ actual ET) are shown in Table 5. Actual ET was obtained from the $I_{2}$ irrigation treatment. Ratios of 1.54, 1.30 and 1.0 were recorded in 2010 for Penman-Monteith, Doorenbos-Pruitt, and Evaporation Pan Equations respectively. In 2011 the corresponding ratios were 1.42, 1.23and 1.05 for the same respective formulas. The overall averages for the 2 seasons are $1.48,1.27$ and 1.02 for the same respective equations. The Evaporation Pan formula was the closest compared with the other equations because the ET crop calculated from this formula was slightly differed from the actual ET value. The ET crop calculated due to Doorenbos-Pruitt was the second closest to actual ET after the Evaporation Pan while the value of the Penman-Monteith formulae differed widely from actual ET.

\section{Water use efficiency WUE}

Water use efficiency, is used to show the fruit yield production $(\mathrm{kg})$ per unit of water. It appears from Fig. 3 that this trait was markedly profitable under the medium soil moisture stress level (40\%), as it registered 1.21 and $1.33 \mathrm{Kg}$. fruit yield $/ \mathrm{m}^{3}$ water of irrigation in the first and second seasons, respectively. Whereas the wet treatment produced the least value 1.02 and $1.17 \mathrm{Kg}$. fruit yield $/ \mathrm{m}^{3}$ irrigation water in both seasons, respectively. This means that apricot trees favors medium watering and high production prefers medium soil moisture than lower and high watering. Ritchie (1974) pointed out that, water conservation benefits can be obtained by allowing plants to experience moderate water stress. When roots are subjected to soil moisture stress, extraction of soil water from greater depths would occur therefore, water stored in the profile is used more efficiently. Smajstrla and Koo (1984) found that irrigation of selected trees was initiated during the growth stages before and after June. They suggested that irrigation is required to keep soil moisture tension between $40-60$ mbar at $30 \mathrm{~cm}$

Egypt. J. Hort. Vol. 40, No.2 (2013) 
soil depth (i.e. 50\% available water) and this frequency of water application resulted in the highest yields. Roth et al. (1988) found that depletion of a small portion of available soil moisture and found that irrigation upon depletion of 40 $\%$ of available soil moisture gave the highest water use efficiency.

TABLE 4. Crop coefficient (Kc), ETcrop for Penman Monteith, Doorenbos- Pruitt and Evaporation Pan formulae and actual ET for apricot trees in 2010 and 2011 seasons.

\begin{tabular}{|c|c|c|c|c|c|c|c|c|c|}
\hline \multicolumn{10}{|c|}{2010} \\
\hline \multirow{2}{*}{ Month } & \multirow{2}{*}{ Kc } & \multicolumn{2}{|c|}{$\begin{array}{c}\text { Penman } \\
\text { Monteith }\end{array}$} & \multicolumn{2}{|c|}{$\begin{array}{c}\text { Doorenbos \& } \\
\text { Pruitt }\end{array}$} & \multicolumn{2}{|c|}{$\begin{array}{l}\text { Evaporation } \\
\text { Pan }\end{array}$} & \multicolumn{2}{|c|}{ Actual ET } \\
\hline & & $\begin{array}{l}\mathrm{mm} / \\
\text { day }\end{array}$ & $\begin{array}{c}\mathrm{mm} / \\
\text { month }\end{array}$ & $\begin{array}{l}\mathrm{mm} / \\
\text { day }\end{array}$ & $\begin{array}{c}\mathrm{mm} / \\
\text { month }\end{array}$ & $\begin{array}{l}\mathrm{mm} / \\
\text { day }\end{array}$ & $\begin{array}{c}\mathrm{mm} / \\
\text { month }\end{array}$ & $\begin{array}{l}\mathrm{mm} / \\
\text { day }\end{array}$ & $\begin{array}{c}\mathrm{mm} / \\
\text { month }\end{array}$ \\
\hline February & 0.61 & 3.3 & 92.4 & 2.84 & 79.5 & 1.74 & 53.9 & 2.01 & 56.3 \\
\hline March & 0.68 & 4.4 & 136.4 & 3.78 & 117.2 & 2.33 & 72.2 & 2.97 & 92.1 \\
\hline April & 0.65 & 5.6 & 168.0 & 4.73 & 141.9 & 3.42 & 102.6 & 3.63 & 108.9 \\
\hline May & 0.64 & 6.7 & 207.7 & 5.71 & 177.0 & 4.55 & 141.1 & 4.30 & 133.3 \\
\hline June & 0.65 & 7.3 & 219.0 & 6.39 & 191.7 & 4.77 & 143.1 & 4.77 & 143.1 \\
\hline July & 0.74 & 7.1 & 220.1 & 6.09 & 188.8 & 4.94 & 153.1 & 5.24 & 162.4 \\
\hline August & 0.63 & 7 & 217.0 & 5.88 & 182.3 & 4.95 & 153.5 & 4.40 & 136.4 \\
\hline September & 0.61 & 6.1 & 183.0 & 5.05 & 151.5 & 3.92 & 117.6 & 3.70 & 111.0 \\
\hline October & 0.59 & 5.2 & 161.2 & 3.97 & 123.1 & 3.14 & 97.34 & 3.09 & 95.79 \\
\hline $\begin{array}{l}\text { Seasonal } \\
(\mathbf{m m})\end{array}$ & 0.65 & & 1605 & & 1353 & & 1034 & & 1039 \\
\hline \multicolumn{10}{|c|}{2011} \\
\hline February & 0.72 & 3.07 & 89.0 & 2.81 & 78.7 & 1.78 & 55.2 & 2.08 & 64.5 \\
\hline March & 0.72 & 4.23 & 131.1 & 3.62 & 112.2 & 2.33 & 72.2 & 3.04 & 94.2 \\
\hline April & 0.69 & 532 & 160.5 & 455 & 136.8 & 3.48 & 104.4 & 3.70 & 111.0 \\
\hline May & 0.65 & $\begin{array}{l}5.35 \\
674\end{array}$ & 208.9 & $\begin{array}{l}4.50 \\
5.61\end{array}$ & 173.9 & 4.68 & 145.1 & 4.39 & 136.1 \\
\hline June & 0.67 & $\begin{array}{l}0.14 \\
7.25\end{array}$ & 217.5 & $\begin{array}{l}5.01 \\
626\end{array}$ & 187.8 & 5.54 & 166.2 & 4.87 & 146.1 \\
\hline July & 0.71 & $\begin{array}{l}1.25 \\
7.48\end{array}$ & 231.9 & $\begin{array}{l}0.20 \\
621\end{array}$ & 192.5 & 5.76 & 178.6 & 5.33 & 165.2 \\
\hline August & 0.81 & $\begin{array}{l}1.48 \\
574\end{array}$ & 177.9 & $\begin{array}{l}6.21 \\
571\end{array}$ & 177.0 & 5.57 & 172.7 & 4.65 & 144.2 \\
\hline September & 0.75 & & 160.2 & & 147.3 & 4.33 & 129.9 & 3.98 & 119.4 \\
\hline October & 0.65 & 5.34 & 151.3 & 4.91 & 120.28 & 3.68 & 114.1 & 3.18 & 98.6 \\
\hline $\begin{array}{c}\text { Seasonal } \\
(\mathbf{m m})\end{array}$ & 0.71 & 4.88 & 1528 & 3.88 & 1327 & & 1138 & & 1079 \\
\hline
\end{tabular}

TABLE 5. Ratios of ET crop values calculated by different ET formulae to the actual ET of apricot in 2010 and 2011 seasons .

\begin{tabular}{|c|c|c|c|c|c|c|}
\hline \multirow{2}{*}{ Formulae } & \multicolumn{2}{|c|}{ 2010 } & \multicolumn{2}{c|}{ 2011 } & \multicolumn{2}{c|}{ Average } \\
\cline { 2 - 7 } & ET crop & Ratio & ET crop & Ratio & ET crop & Ratio \\
\hline Penman Monteith & 1605 & 1.54 & 1528 & 1.42 & 1567 & 1.48 \\
Doorenbos- Pruitt & 1353 & 1.30 & 1327 & 1.23 & 1340 & 1.27 \\
Evaporation A Pan & 1034 & 1.00 & 1138 & 1.05 & 1086 & 1.02 \\
Actual ET & 1039 & $\ldots$ & 1079 & $\ldots$ & 1059 & $\ldots$ \\
\hline
\end{tabular}




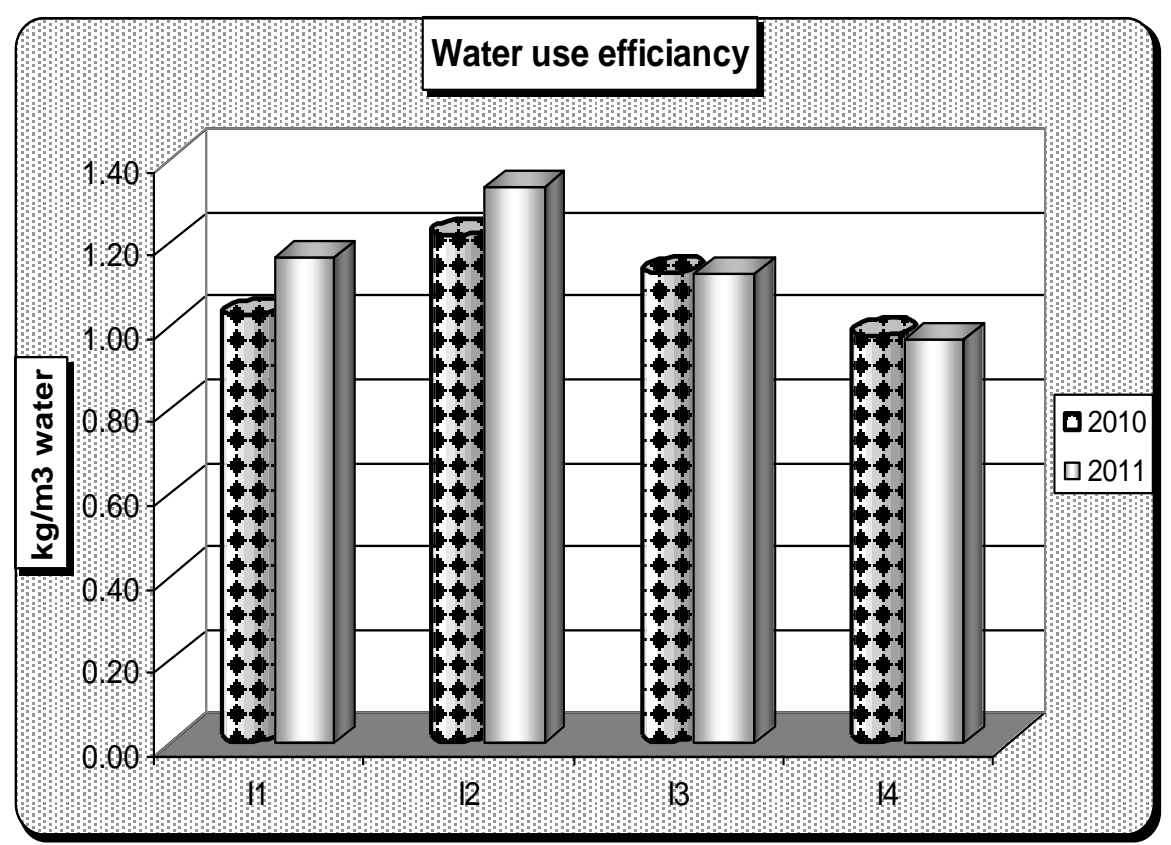

Fig. 3. Water use efficiency (WUE) $\mathrm{kg} / \mathrm{m}^{3}$ by apricot trees under different water regime levels.

Vegetative growth and fruiting parameters

Vegetative growth parameters:

Shoot and leaf growth parameters: The obtained data in Table 6 showed that shoot and leaf parameters of "Canino" apricot trees affected by irrigation rates in 2010 and 2011 seasons. It cleared that shoot length $(\mathrm{cm})$, diameter $(\mathrm{cm})$, leaf area $\left(\mathrm{cm}^{2}\right)$ and leaf dry weight $(\mathrm{g})$ recorded the highest significant values at $I_{1}$ irrigation rate (20\% depletion), while showed gradually decrease with irrigation rate reduction. Data were in harmony at both studied seasons. However, Alkinson et al. (2000) reported that drought stress caused an increase in abscissic acid production in the root and transportation to the shoot. The increase in ABA could reduce shoot growth and leaf expansion of "Queen Cox" apple trees. Also, water stress reduces the capacity of the protoplasm to carry on photosynthesis. In addition, this reduction in the trees growth under water stress could be related to lower photosynthetic rates and stomatal conductance (Mpelasoka et al., 2001) which decrease the supply of $\mathrm{Co}_{2}$. These results were in agreement with those obtained by Chalmers et al. (1981) who mentioned that the growth of peach trees was inhibited with reduced irrigation than with full irrigation. Furthermore, Abd El-Messeih and El-Gendy (2004a) on "Canino" apricot; Mikhael (2007a) on "Anna" apple; Hussein et al. (2008) on apricot and Mikhael et al. (2010) on "Dessert Red" peach, reported that shoot and leaf growth were reduced under the low drip or flood irrigation rates. 
TABLE 6. Effect of different irrigation levels on shoot length, shoot diameter, leaf area and leaf dry weight of "Canino" apricot trees during two seasons.

\begin{tabular}{|c|c|c|c|c|}
\hline \multicolumn{5}{|c|}{2010} \\
\hline $\begin{array}{l}\text { Irrigation } \\
\text { regimes }\end{array}$ & $\begin{array}{c}\text { Shoot length } \\
(\mathrm{cm})\end{array}$ & $\begin{array}{c}\text { Shoot diameter } \\
\text { (cm) }\end{array}$ & $\begin{array}{l}\text { Leaf area } \\
\left(\mathrm{cm}^{2}\right)\end{array}$ & $\begin{array}{l}\text { Leaf dry weight } \\
\text { (g) }\end{array}$ \\
\hline$* \mathbf{I}_{1}$ & $62.19 \mathrm{~A}$ & $1.230 \mathrm{~A}$ & $36.40 \mathrm{~A}$ & $0.450 \mathrm{~A}$ \\
\hline $\mathbf{I}_{2}$ & $45.65 \mathrm{~B}$ & $1.000 \mathrm{~B}$ & $28.19 \mathrm{~B}$ & $0.407 \mathrm{~B}$ \\
\hline $\mathbf{I}_{3}$ & $33.34 \mathrm{C}$ & $0.810 \mathrm{C}$ & $27.13 \mathrm{C}$ & $0.380 \mathrm{C}$ \\
\hline $\mathbf{I}_{4}$ & $25.05 \mathrm{D}$ & $0.650 \mathrm{CD}$ & $21.72 \mathrm{D}$ & $0.316 \mathrm{D}$ \\
\hline \multicolumn{5}{|c|}{2011} \\
\hline $\mathbf{I}_{\mathbf{1}}$ & $50.30 \mathrm{~A}$ & $1.120 \mathrm{~A}$ & $35.00 \mathrm{~A}$ & $0.544 \mathrm{~A}$ \\
\hline $\mathbf{I}_{2}$ & $46.13 \mathrm{~B}$ & $0.950 \mathrm{~B}$ & 28.84B & $0.485 B$ \\
\hline $\mathbf{1}_{3}$ & $36.55 \mathrm{C}$ & $0.770 \mathrm{C}$ & $25.06 \mathrm{C}$ & $0.440 \mathrm{BC}$ \\
\hline $\mathbf{I}_{4}$ & $27.72 \mathrm{D}$ & $0.530 \mathrm{D}$ & $20.50 \mathrm{D}$ & $0.337 \mathrm{D}$ \\
\hline
\end{tabular}

* $\mathrm{I}_{1}$ Irrigation when $20 \%$ available soil moisture is depleted (wet)

$\mathrm{I}_{2}$ Irrigation when $40 \%$ available soil moisture is depleted.

$\mathrm{I}_{3}$ Irrigation when $60 \%$ available soil moisture is depleted.

$\mathrm{I}_{4}$ Irrigation when $80 \%$ available soil moisture is depleted (dry)

\section{Fruit set percentage and yield}

Data in Table 7 revealed that the highest fruit set percentage (23.3 and $25.2 \%)$ and fruit yield (31.55 and $35.40 \mathrm{~kg}$ ) were accompanied with $40 \%$ water depletion $\left(\mathrm{I}_{2}\right)$, while decreased markedly with higher $\left(\mathrm{I}_{1}\right)$ or lower $\left(\mathrm{I}_{3}\right.$ and $\left.\mathrm{I}_{4}\right)$ irrigation rates. However, the difference was statistically confirmed except between $I_{1}$ and $I_{2}$ fruit set in 2011 season. The lowest fruit set percentage was induced by the deficit water irrigation rate $\left(\mathrm{I}_{4}\right)$. These results were in harmony with those noticed by Skepper and Vircent (1962) who reported that 4-5 weeks water shortage before blooming resulted in a reduction in fruit setting in deciduous trees. Also, Ali et al. (1998) found that maintaining soil moisture at high level (20\% depletion) caused a significant decrease in peach fruit setting compared with the other irrigation treatments. At the same time, more water stored in the root zone of apple trees may cause a reduction in fruit setting due to their effect either on aeration or on the growth of roots. Moreover, in this study at low moisture levels (dry), it showed a significant decrease in fruit set \%. Also, all previous data were in line with Abd El-Messeih and El-Gendy (2004a) and Mikhael and Mady (2007b). In this respect, George and Nissen (2002) indicated that, as the severity of drought increased, fruit set was reduced. Such results might be due to lower photosynthetic rates under deficit irrigation regime. As for yield ( $\mathrm{kg}$ fruits/tree), it could be noticed that water deficit had a significant effect on productivity of apricot trees. The maximum fruit yield and yield efficiency Fig. 3 were scored from $I_{2}$ followed by $I_{1}$. The lowest significant production was induced by the dry soil moisture level in both studied seasons. Ali et al. (1998) pointed out that such type of foundations may prove the importance of maintaining soil moisture at an optimum level (40\% depletion.) for increasing the retained fruits on apple trees.

Egypt. J. Hort. Vol. 40, No.2 (2013) 
TABLE 7. Effect of different irrigation levels on fruit set \% and yield (kg/tree) of "Canino" apricot trees during the two experimental seasons.

\begin{tabular}{|c|c|c|c|}
\hline \multicolumn{4}{|c|}{$\mathbf{2 0 1 0}$} \\
\hline $\begin{array}{c}\text { Irrigation } \\
\text { regimes }\end{array}$ & Fruit set \% & Yield (kg/tree) & Firmness (Ib/inch $\left.^{\mathbf{2}}\right)$ \\
\hline $\mathbf{I}_{\mathbf{1}}$ & $20.81 \mathrm{~B}$ & $28.90 \mathrm{~B}$ & $5.32 \mathrm{D}$ \\
$\mathbf{I}_{\mathbf{2}}$ & $23.30 \mathrm{~A}$ & $31.55 \mathrm{~A}$ & $5.89 \mathrm{CD}$ \\
$\mathbf{I}_{\mathbf{3}}$ & $18.62 \mathrm{C}$ & $24.70 \mathrm{C}$ & $6.64 \mathrm{~B}$ \\
$\mathbf{I}_{\mathbf{4}}$ & $16.53 \mathrm{D}$ & $19.53 \mathrm{D}$ & $7.22 \mathrm{~A}$ \\
\hline \multicolumn{4}{|c|}{$\mathbf{2 0 1 1}$} \\
\hline $\mathbf{I}_{\mathbf{1}}$ & $24.50 \mathrm{~A}$ & $33.62 \mathrm{~B}$ & $5.60 \mathrm{D}$ \\
$\mathbf{I}_{\mathbf{2}}$ & $25.20 \mathrm{~A}$ & $35.40 \mathrm{~A}$ & $6.00 \mathrm{C}$ \\
$\mathbf{1}_{\mathbf{3}}$ & $19.07 \mathrm{~B}$ & $27.00 \mathrm{C}$ & $6.58 \mathrm{~B}$ \\
$\mathbf{I}_{\mathbf{4}}$ & $16.66 \mathrm{C}$ & $20.11 \mathrm{D}$ & $7.53 \mathrm{~A}$ \\
\hline
\end{tabular}

Fruit quality

Physical fruit properties (weight, volume, length and diameter)

Data in Table 8 showed that all the fruit characteristics were significantly affected by water deficit. The highest values were resulted from I1 and I2 followed by I3 (medium). Generally, the lowest values were gained from the severe soil moisture stress. Results were true under both studied seasons. These results were supported by Behboudian et al. (1994). Also, Mpelasoka et al. (2001) stated that effect of deficit irrigation on reduced average fruit weight and volume could be due to the reduction in fruit cell enlargement by reducing fruit turgor early in the season and decrease cell water content.

TABLE 8. Effect of different irrigation levels on fruit weight $(\mathrm{g})$, fruit volume $\left(\mathrm{cm}^{3}\right)$ and fruit length $(\mathrm{cm}) \&$ diameter $\left(\mathrm{cm}^{2}\right)$ of "Canino" apricot trees during the two experimental seasons.

\begin{tabular}{|c|c|c|c|c|}
\hline \multicolumn{5}{|c|}{$\mathbf{2 0 1 0}$} \\
\hline $\begin{array}{c}\text { Irrigation } \\
\text { regimes }\end{array}$ & $\begin{array}{c}\text { Fruit weight } \\
(\mathbf{g} .)\end{array}$ & $\begin{array}{c}\text { Fruit volume } \\
\left(\mathbf{c m}^{\mathbf{3}}\right)\end{array}$ & $\begin{array}{c}\text { Fruit length } \\
(\mathbf{c m})\end{array}$ & $\begin{array}{c}\text { Fruit diameter } \\
(\mathbf{c m})\end{array}$ \\
\hline $\mathbf{I}_{\mathbf{1}}$ & $57.86 \mathrm{~B}$ & $50.20 \mathrm{~A}$ & $5.30 \mathrm{~B}$ & $4.82 \mathrm{~B}$ \\
$\mathbf{I}_{\mathbf{2}}$ & $65.01 \mathrm{~A}$ & $47.40 \mathrm{~B}$ & $5.58 \mathrm{~A}$ & $5.08 \mathrm{~A}$ \\
$\mathbf{I}_{\mathbf{3}}$ & $53.40 \mathrm{C}$ & $41.10 \mathrm{C}$ & $4.40 \mathrm{C}$ & $4.20 \mathrm{C}$ \\
$\mathbf{I}_{\mathbf{4}}$ & $46.97 \mathrm{D}$ & $36.20 \mathrm{D}$ & $3.35 \mathrm{C}$ & $3.78 \mathrm{D}$ \\
\hline \multicolumn{5}{|l|}{} \\
\hline \multicolumn{5}{|l}{$\mathbf{2 0 1 1}$} \\
$\mathbf{I}_{\mathbf{I}}$ & $67.20 \mathrm{~A}$ & $46.70 \mathrm{~B}$ & $5.04 \mathrm{~B}$ & $4.95 \mathrm{~A}$ \\
$\mathbf{I}_{\mathbf{1}}$ & $52.57 \mathrm{~B}$ & $49.03 \mathrm{~A}$ & $5.36 \mathrm{~A}$ & $4.90 \mathrm{~A}$ \\
$\mathbf{I}_{\mathbf{4}}$ & $48.83 \mathrm{C}$ & $39.02 \mathrm{C}$ & $4.57 \mathrm{C}$ & $4.40 \mathrm{~B}$ \\
& $43.98 \mathrm{D}$ & $34.03 \mathrm{D}$ & $3.95 \mathrm{D}$ & $4.00 \mathrm{C}$ \\
\hline
\end{tabular}


Fruit firmness

With regard to fruit firmness it could be noticed that reducing irrigation rate caused significant higher of fruit firmness especially at deficit irrigation rate (I4). The lowest significant value of fruit firmness was induced by I1. Data was in harmony during two studied seasons. Higher firmness may be a result to smaller fruit exhibit the effect of water stress at cell enlargement stage. These results were confirmed with Ali et al. (1998), Abd El-Messeih \& El-Gendy (2004a) and Mikhael \& Mady (2007b) who reported that deficit irrigation induced significantly higher firmness.

Chemical fruit properties

Total sugars, total soluble solids, acidity, TSS/acid ratio in fruit juice and leaf total chlorophyll content

As for TSS and total sugars fruit content in Table 9 appeared that, TSS and TSS/acid ratio, in both seasons, significantly decreased with increasing irrigation water intervals, it reached to the maximum value when trees were supposed to irrigation at $\mathrm{I}_{1}$. Generally, the lowest statistical values of TSS fruit content were recorded at deficit irrigation rate $\left(\mathrm{m}^{3}\right.$ /tree/year) due to the reduced net photosynthesis under drought condition. These results were in the same line with Abd El-Messeih and El-Gendy (2004a) on apricot.

Moreover, total sugars recorded the same trend of TSS. It was in harmony with Abd El-Messeih and El-Gendy (2004a). In addition, no definite trend was found with irrigation treatments by Abou Garah et al. (2009) on persimmon.

TABLE 9. Effect of different irrigation levels on total sugars (\%), TSS (\%), acidity $(\%)$, TSS/acid ratio in fruit juice leaf chlorophyll content of "Canino" apricot trees during the two experimental seasons.

\begin{tabular}{|c|c|c|c|c|c|}
\hline \multicolumn{6}{|c|}{2010} \\
\hline $\begin{array}{c}\text { Irrigation } \\
\text { regimes }\end{array}$ & $\begin{array}{c}\text { Total } \\
\text { sugars } \% \\
\end{array}$ & TSS \% & Acidity \% & $\begin{array}{c}\text { TSS/acid } \\
\text { Ratio }\end{array}$ & $\begin{array}{c}\text { Chlorophyll } \\
\text { (SPAD) }\end{array}$ \\
\hline$I_{1}$ & $58.50 \mathrm{~A}$ & $15.50 \mathrm{~A}$ & $0.690 \mathrm{D}$ & $22.46 \mathrm{~A}$ & $43.20 \mathrm{~A}$ \\
\hline $\mathbf{I}_{2}$ & $54.03 \mathrm{~B}$ & $15.20 \mathrm{~B}$ & $0.720 \mathrm{C}$ & 21.11B & $38.80 \mathrm{~B}$ \\
\hline $\mathbf{I}_{3}$ & $49.70 \mathrm{C}$ & $14.70 \mathrm{C}$ & $0.770 \mathrm{~B}$ & $19.09 \mathrm{C}$ & $34.00 \mathrm{C}$ \\
\hline $\mathbf{I}_{4}$ & 45.60D & $14.02 \mathrm{D}$ & $0.840 \mathrm{~A}$ & 16.69D & $31.20 \mathrm{D}$ \\
\hline \multicolumn{6}{|c|}{2011} \\
\hline $\mathbf{I}_{1}$ & $56.71 \mathrm{~A}$ & $15.04 \mathrm{~A}$ & $0.750 \mathrm{D}$ & $20.05 \mathrm{~A}$ & $38.43 \mathrm{~A}$ \\
\hline $\mathbf{I}_{2}$ & $53.70 \mathrm{~B}$ & $14.81 \mathrm{~A}$ & $0.800 \mathrm{C}$ & $18.51 \mathrm{~B}$ & $36.62 \mathrm{~B}$ \\
\hline $\mathbf{1}_{3}$ & $49.63 \mathrm{C}$ & $14.40 \mathrm{~B}$ & $0.850 \mathrm{~B}$ & $16.94 \mathrm{C}$ & $32.58 \mathrm{C}$ \\
\hline $\mathbf{I}_{4}$ & $46.82 \mathrm{D}$ & $13.80 \mathrm{C}$ & $0.910 \mathrm{~A}$ & $15.16 \mathrm{D}$ & $31.00 \mathrm{C}$ \\
\hline
\end{tabular}

From data in both studied seasons it was obvious that, fruits produced from trees grown under dry conditions were significantly higher in the values of juice acidity. The lowest value was obtained from irrigation level $\left(\mathrm{I}_{1}\right)$. Similar results were reported by Perez-Pastor et al. (2007) on apricot. On the other hand,

Egypt. J. Hort. Vol. 40, No.2 (2013) 
Abd El-Messeih and El-Gendy (2004a) stated that acidity decreased with decreasing applied irrigation water.

It was clear from Table 9 that, leaf chlorophyll content at both seasons gradually decreased with decreasing water irrigation rate with significant differences between irrigation levels. These results appeared that a positive impact between soil moisture level and leaf chlorophyll content. This increase in leaf chlorophyll could be related to increase the uptake of $\mathrm{N}$ an $\mathrm{Mg}$ elements are necessary for chlorophyll synthesis (Mengle and Kirkby, 1982). The same results were supported by Abd El-Messeih and El-Gendy (2004b) and Mikhael et al., (2010) worked on apricot and peach, respectively.

\section{Macro and micro elements leaf contents}

Data in Table 10 it mentioned that, reducing irrigation rate caused gradually significant reduction in leaf $\mathrm{N}, \mathrm{P}, \mathrm{K}, \mathrm{Fe}$ and $\mathrm{Zn}$ content. The same trend was clear in the second season. However, no definite trend was cleared with Mn leaf content. These results may be lead to the conclusion that nutrient uptake was retarded under water stress conditions where the roots failed to absorb and accumulate valuable nutrient elements. Furthermore, depletion of soil moisture level caused a reduction in leaf mineral contents as a result of reduced active rooting as an indirect effect (Abd El-Messeih and El-Gendy, 2004b) on apricot trees.

TABLE 10. Effect of different irrigation levels on some macro and micro nutrients of "Canino" apricot trees during two seasons.

\begin{tabular}{|c|c|c|c|c|c|c|}
\hline \multicolumn{7}{|c|}{2010} \\
\hline $\begin{array}{c}\text { Irrigation } \\
\text { regimes }\end{array}$ & N\% & $\mathbf{P \%}$ & K\% & Fe ppm & Zn ppm & Mn ppm \\
\hline$I_{1}$ & $2.50 \mathrm{~A}$ & $0.32 \mathrm{~A}$ & $1.50 \mathrm{~A}$ & $122.3 \mathrm{~A}$ & 19.90A & $50.20 \mathrm{~A}$ \\
\hline $\mathbf{I}_{2}$ & $2.20 \mathrm{~B}$ & $0.28 \mathrm{~B}$ & $1.20 \mathrm{~B}$ & 111.1B & 17.60B & $38.20 \mathrm{C}$ \\
\hline $\mathbf{I}_{3}$ & $1.95 \mathrm{C}$ & $0.23 \mathrm{C}$ & $1.00 \mathrm{C}$ & $99.40 \mathrm{C}$ & $15.00 \mathrm{BC}$ & $34.00 \mathrm{D}$ \\
\hline $\mathbf{I}_{4}$ & $1.80 \mathrm{D}$ & $0.20 \mathrm{CD}$ & $0.82 \mathrm{D}$ & 89.70D & $12.10 \mathrm{C}$ & 43.10B \\
\hline \multicolumn{7}{|c|}{2011} \\
\hline $\mathbf{I}_{1}$ & $2.35 \mathrm{~A}$ & $0.29 \mathrm{~A}$ & $1.60 \mathrm{~A}$ & $131.2 \mathrm{~A}$ & $21.60 \mathrm{~A}$ & $25.00 \mathrm{D}$ \\
\hline $\mathbf{I}_{2}$ & $2.00 \mathrm{~B}$ & $0.26 \mathrm{~B}$ & $1.40 \mathrm{~B}$ & 125.0B & $19.70 \mathrm{~A}$ & 46.20B \\
\hline $\mathbf{1}_{3}$ & $1.90 \mathrm{~B}$ & $0.22 \mathrm{C}$ & $1.32 \mathrm{C}$ & $119.3 \mathrm{C}$ & $15.50 \mathrm{~B}$ & $48.60 \mathrm{~A}$ \\
\hline $\mathbf{I}_{4}$ & $1.52 \mathrm{C}$ & $0.19 \mathrm{D}$ & $1.22 \mathrm{D}$ & $115.1 \mathrm{C}$ & $11.40 \mathrm{C}$ & $39.50 \mathrm{C}$ \\
\hline
\end{tabular}

\section{References}

Abd Alla, I.M., Nadia S. Shafshak, Abo-Sedera F.A. and Abd El-Rahman, L.A. (1990) Effect of water regime and level on NPK fertilization on carrot 1- vegetative growth and its chemical composition. Annals of Agric. Sc. Moshtohor, 28(4), 2517 -2528.

Abd El-Messeih, W.M. and El-Gendy, R.W. (2004a) Effect of different trickle irrigation levels based on soil matric potential on; 1- Vegetative growth and yield of "Canino" apricot trees planted in sandy soils. Alex. Sci. Exch., 25 (3), 465-480. 
Abd El-Messeih, W.M. and El-Gendy, R.W. (2004b) Effect of different trikle irrigation levels based on soil matric potential on; 2- Leaf chemical composition and active rooting depth of "Canino" apricot trees planted in sandy soils. Alex. Sci. Exch., 25 (3), 465-480.

Abou-Garah, F.I., Hussein, S.M. and Eid, T.A. (2009) Response of persimmon trees on clay loamy soils to different irrigation levels. Annals of Agric. Sc., Moshtohor, 47 (1), 91-110.

Ali, M.M. (2006) Effect of different irrigation rates and emitter distances on vegetative growth, fruiting and water use efficiency (WUE) for Florida prince peach cultivar trees. Egypt. J. App. Sci., 21 (1), 184-204.

Ali, M.A., Mahmoud, H.M. and Salib, A.Y. (1998) Effect of Soil moisture stress on apple trees. Egypt. J. Agric. Res., 76 (4), 1565-1583.

Alkinson, C.J., Webster, A. Vaughan, S.P. Taylor, L. and Kingswell, G. (2000) Interaction between root restriction, irrigation and rootstock treatments on "Queen Cox" apple trees: Effect of soil and plant water relations. J. Hort. Biotech., 75 (4), 376-382.

Allen, R.G., Pereira, L.S., Raes, D. and Smith, M. (1998) Crop evapotranspiration irrigation and Drainage Paper No. 56, FAO, Rome, Italy.

A.O.A.C. (1990). Association of Official Agricultural Chemists. Official Methods of Analysis. $12^{\text {th }}$ ed. Washington, D. C., USA.

Behboudian, M.H., Lawes, G.S. and Grifiths, K.M. (1994) The influence of water deficit on water relation, photosynthesis and fruit growth in asian pear (Pyrus serotina. Rehd.) Scientia Horticulturae, 60, 89-99.

Cathoun, F.G. (1975) Influence of particle size and organic matter on water tension in selected Florida soils. Proc. Soil and Crop Sci. of Florida, 32, 111-113.

Chalmers, D.J., Mitchell, P.D. and Van Heek, L. (1981) Control of peach tree growth and productivity by regulated water supply, tree density and summer pruning. $J$. Amer. Soc. Hort. Sci., 106 (3), 307-312.

Chang, J.H. (1971) Climate and Agriculture. An Ecological survey. Aldine publishing company. Chicago.

Chapman, H.D. and Pratt, F. (1961) “Methods of Analysis for Soils, Plants and Water". Univ. of Calif., 35 (5), 6-7.

Costa, J.M., Ortuno, M.F. and Chaves, M.M. (2007) Deficit irrigation as a strategy to save water: physiology and potential application to horticulture. J. Integr. Plant Bio. 149, 1421-1434.

Domingo, R., Ruiz-Sa`nchez, M.C. Sa`nchez-Blanco, M.J. and Torrecillas, A. (1996) Water relations, growth and yield of Fino lemon trees under regulated deficit irrigation. Irrig. Sci., 16, 115-123. 
Doorenbos, J. and KASAM, A.H. (1986) Yield response to water. Irrigation and Drainage Paper No. 33, FAO, Rome, Italy.

Doorenbos, J. and Pruitt, W.O. (1984) "Guidelines for predicting crop water requirements". FAO Irrigation and Drainage Paper No. 24, (revised) FAO, Rome, Italy.

Doorenbos, J. and Pruitt, W.O. (1977) Guidelines for predicting crop water requirements. FAO Irrigation and Drainage Paper No. 24, (revised) FAO, Rome, Italy.

Duncan, D.B. (1955) Multiple range and multiple F. Tests biometrics , 11, 1- 24.

George, A.B. and Nissen, R.J. (2002) Effect of drought on fruit set, yield and quality of "Custard" apple (Annona spp. Hybrid) "African Pride" plants, J. Hort. Biotech., 77 (4), 418-427.

Girona, J., Marsal, J. Mata, M. Arbones, A. and Miravete, C. (1997) Evaluation of almond (Prunus amygdalus L.) seasonal sensitivity to water stress. Acta Hort., 449, 489-496.

Goldhamer, D.A. (1997) Regulated deficit irrigation of fruit and nut trees. Int. Water Irrg. Rev., 17, 14-19.

Hussein, S.M., Fathi, M.A. and Abou-Garah, F.I. (2008) Effect of irrigation rate and soil type on "Canino" apricot trees. Annals of Agric. Sci. Moshtohor, 46 (3), 385-393.

Ibrahim, M.A. (1981) Evaluation of different methods for calculating potential evopotranspiration in north Delta region, Ph. D. Thesis, Fac. Agri. Alex. Univ. Egypt.

Israelsen, O.W. and Hansen, V.E. (1962) Irrigation Principles and Practices, $3^{\text {rd }}$ ed., John Willey and Sons Inc., New York, USA.

Jackson, M.L. and Ulrich, A. (1959) Analytical methods for use in plant analysis. Coll. of Agric. Exp. State Bull.766, 35 p.

Jensen, M.E. (1968) Water consumption by Agriculture lands, In. Water deficit and plant growth, T.T. Kozlowski (Ed.), Academa press, New York. Vol. II. 1-22.

Kandil, E.A. and El-Feky, S. (2006) Effect of soil matric potential on "Canino" apricot trees in sandy soil under drip irrigation. J. Agric. Sci. Mansoura Univ.

Levin, I., Assaf, R. and Bravdo, B.A. (1980) Irrigation water status and nutrient uptake in apple orchard. Butterworths Borough, Green UK p. 230.

Magness, J.R. and Taylor, G.F. (1925) An improved type of preeur tester for the determination of fruit maturity. U. S. Dept. Agric. CIRC., 3508p.

Makkink, G.F. (1957) Testing the penman formula by means of lysimeters. J. Inst.Water Eng, 11, 277-278.

Mengle, K. and Kirkby, E.A. (1982) Principal of Plant Nutrition. Bern. Switzerland. Inst. Potash. Inst., p. 520.

Egypt. J. Hort. Vol. 40, No.2 (2013) 
Malik, C.P. and Singh, M.B. (1980) Plant Enzymology and Isoenzymology. A text manual Kalyand, Publishers; New Delhi, India.

Mikhael, G.B. (2007a) Effect of some drip irrigation and mulching treatments on: 1Vegetative growth and nutritional status of "Anna" apple trees grown in new reclaimed soils. Minufiya J. Agric. Res., 32 (4), 1155-1174.

Mikhael, G.B., Aziz, M.A. and Abd El-Messeih, W.M. (2010) Effect of some flood irrigation and potassium fertilization treatments on vegetative growth, yield and fruit quality of "Dessert Red" peach trees grown in clay soil. J. Plant Production, 1 (4), 599-620.

Mikhael, G.B. and Mady, A.A. (2007b) Effect of some drip irrigation and mulching treatments on: 2- Yield, fruit quality and water use efficiency of "Anna" apple trees grown in new reclaimed soils. Minufiya J. Agric. Res., 32 (4), 1175-1191.

Mpelasoka, B., Behboudian, M.H. and Mills, T.M. (2001) Water relation, photosynthesis, growth, yield and fruit size of apple responses to deficit irrigation and to crop load. J. Hort. Sci. Biotech., 67 (2), 150-156.

Murquard, R.D. and Timpton, J.L. (1987) Relationship between extractable chlorophyll and the method to estimate leaf green. Hort. Sci., 22 (6), 1327.

Perez-Pastor, A., Ruiz-Sanchez, M.C. Martinez, J.A. Nortes, P.A. Artes, F. and Domingo, R. (2007) Effect of deficit irrigation on apricot fruit quality at harvest and during storage. J. Sci. food and Agric., 87 (13), 2409-2415.

Pregl, E. (1945) Quantitative Organic Micro Analysis. $4^{\text {th }}$ ed. Chundril, London.

Ritchie, J.T. (1974) Atmosphere and the plant balance. Agric. Meteorol., 14, 183-198.

Roth, D., Kachel, K. Teichardt, R. and Schalitz, G. (1988) Results and recommendation for splinkler irrigation of culinary potatoes. Feldwirtschaft, 29(5), 206-209. Ruggiero, C. (1991): Effect of water regime on apricot [cv. Cufona] in Vesuvian area. Acta Horticulturae, 293, 443-449.

Skepper, A.H. and Vircent, A.E. (1962) Orchard Irrigation. New South Wales Dep. Agric. Publ. 77 p.

Smajstrla, A.G. and Koo, R.C.J. (1984) Effects of trickle irrigation methods and amounts of water applied on citrus yields. Proceeding of the Forida State Horticultural Society. 1984, publ. 1985, 97,3-7.

Smith (1991) "CROPWAT" model for ETo calculation using Penman Monteith Method. FAO, Rome, Italy.

Snedecor, G.W. and W.G. Cochran (1990) Statistical Methods. $7^{\text {th }}$ ed. Iowa State Univ., USA. p. 593.

Snell, F.D. and C.T. Snell (1967) Colorimetric Method of Analysis. D. Van Nestrant Company Inc. pp: 551-552.

Egypt. J. Hort. Vol. 40, No.2 (2013) 
Unger, P.W. and B.A. Steward (1983) Soil Management for Efficient Water Use. An Overview, pp. 419-460 In H.M. Taylor, W.R.

Vites, F.G. (1965) Increasing Water Use Efficiency by Soil Management. Amer. Soc. Agron., Madison,

Vogel, A. (1968) A Text Book of Quantitative Inorganic Analysis, Longmans, New York, pp. 1216. Wisc. pp. 259-274.

\section{تنظيم رى أشجار المشمش تحت معدلات مختلفة من إستنفاذ

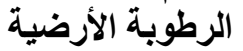

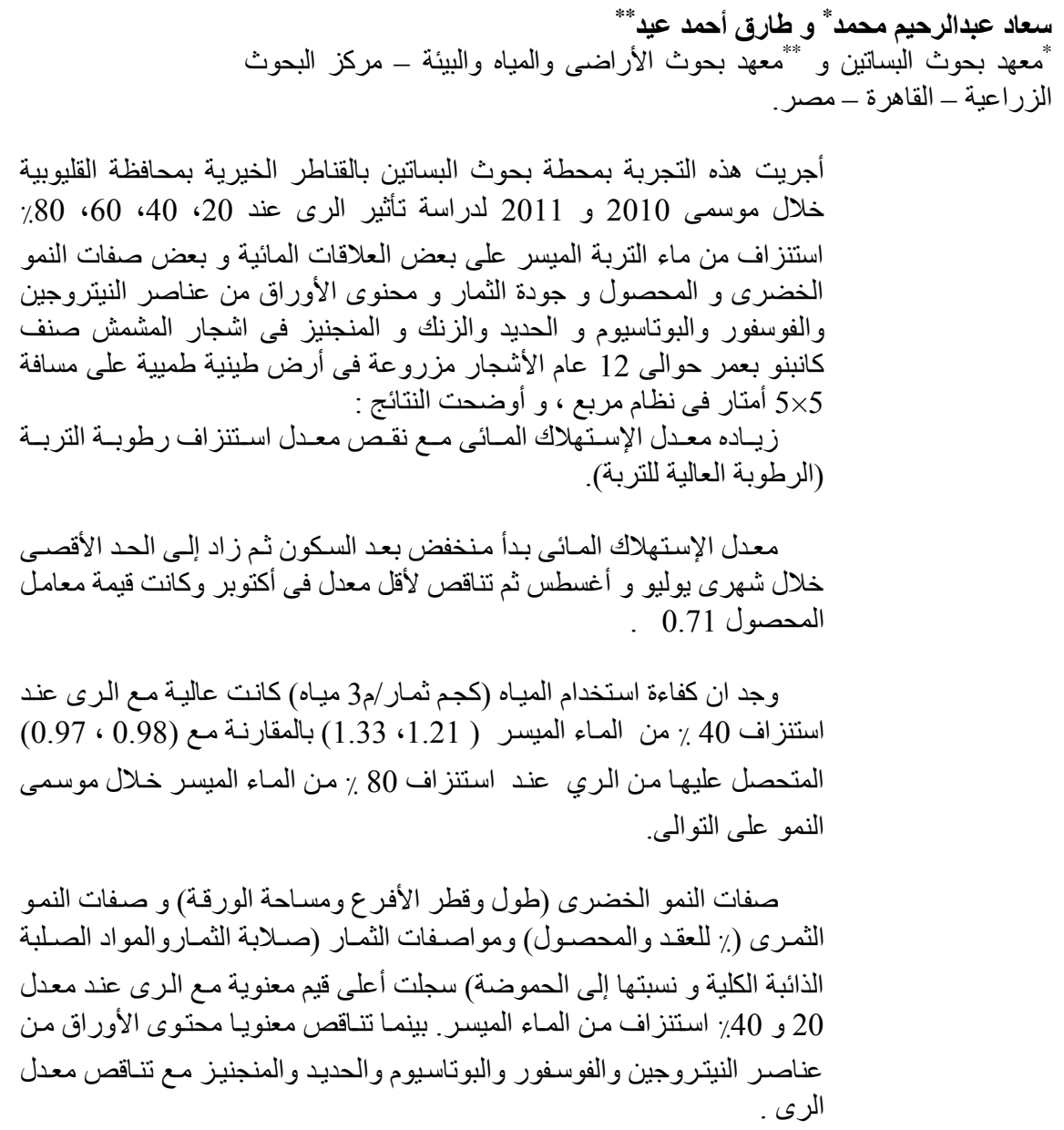

